\title{
Fossil localities of the Santa Cruz Formation (Early Miocene, Patagonia, Argentina) prospected by Carlos Ameghino in 1887 revisited and the location of the Notohippidian
}

\author{
Juan Carlos Fernicola $^{\text {a,b,e,*, José I. Cuitiño }}{ }^{c}$, Sergio F. Vizcaíno ${ }^{\text {d,e }}$, M. Susana Bargo d,f, \\ Richard F. Kay ${ }^{g}$ \\ a Sección Paleontología de Vertebrados, Museo Argentino de Ciencias Naturales “Bernardino Rivadavia”, Av. Ángel Gallardo 470, \\ 1405DJR Ciudad Autónoma de Buenos Aires, Argentina \\ b Departamento de Ciencias Básicas, Universidad Nacional de Luján Ruta 5 y Avenida Constitución, 6700 Luján, Buenos Aires, Argentina \\ ${ }^{c}$ Universidad de Buenos Aires, Departamento de Ciencias Geológicas, Facultad de Ciencias Exactas y Naturales, Intendente Guiraldes 2160 , \\ C1428EHA Ciudad Autónoma de Buenos Aires, Argentina \\ ${ }^{\mathrm{d}}$ División Paleontología Vertebrados, Museo de La Plata, Paseo del Bosque s/n, B1900FWA La Plata, Argentina \\ e CONICET, Argentina \\ ${ }^{\mathrm{f}}$ CIC, Argentina \\ ${ }^{g}$ Department of Evolutionary Anthropology, Box 90383, Duke University, Durham, NC 27708, USA
}

\section{A R T I C L E I N F O}

\section{Article history:}

Received 4 November 2013

Accepted 3 February 2014

\section{Keywords:}

Carlos Ameghino

Río Santa Cruz

Fossil mammals

Santacrucian

Notohippidian

\begin{abstract}
A B S T R A C T
Between January and September of 1887 Carlos Ameghino carried out his first geologic and paleontological expedition to the Río Santa Cruz, Patagonia. Based on the fossils and geologic information compiled, in 1887 and 1889, Florentino Ameghino named more than 120 new species of extinct mammals and his Formación Santacruceña and Piso Santacruceño (Santacrucian stage). Data published by both brothers state that the specimens were collected in outcrops by the Río Santa Cruz, between 90 and $200 \mathrm{~km}$ west of its mouth. However, information in the posthumously published letters and Travel Diary of C. Ameghino allows us to recognize a fourth locality, Río Bote, at about $50 \mathrm{~km}$ further southwest. In 1900, 1902, F. Ameghino divided the Piso Santacruceño in a younger étage Santacruzienne and older étage Notohippidéen, restricting the geographical distribution of the latter to Kar Aiken locality, northeast of Lago Argentino. However, 15 of the 54 species that F. Ameghino listed as exclusively Notohippidian stage already had been named on specimens collected South to the Río Santa Cruz in 1887, two year prior to C. Ameghino's first visit to Kar Aiken. Based on historical information and several expeditions to the Río Santa Cruz and its environs, in this contribution we establish the geographical locations of the 1887 localities, formalize their names, evaluate the stratigraphic position of the fossil-bearing levels, and analyze the geographic extension of the Notohippidian, inferring that Río Bote is where C. Ameghino first collected species that came to define the Notohippidian.
\end{abstract}

(c) 2014 Elsevier Ltd. All rights reserved.

\section{Introduction}

The early Miocene Santa Cruz Formation (SCF) is widely distributed in the Austral geologic basin of Santa Cruz province

\footnotetext{
* Corresponding author. Sección Paleontología de Vertebrados, Museo Argentino de Ciencias Naturales "Bernardino Rivadavia”, Av. Ángel Gallardo 470, 1405DJR Ciudad Autónoma de Buenos Aires, Argentina. Tel.: +54 114982 6595int190; fax: +54 114982 1154/4494/5243

E-mail addresses: jctano@macn.gov.ar, jctano@yahoo.com (J.C. Fernicola), jicuiti@yahoo.com.ar (J.I. Cuitiño), vizcaino@fcnym.unlp.edu.ar (S.F. Vizcaíno), msbargo@fcnym.unlp.edu.ar (M.S. Bargo), richard.kay@duke.edu (R.F. Kay).
}

Argentina, in southern Patagonia (Fig. 1). It is composed of mudstones, tuffaceous sandstones and tuffs, deposited in fluvial environments under the influence of intense explosive pyroclastic input (Feruglio, 1949; Furque and Camacho, 1972; Bown and Fleagle, 1993; Tauber, 1994, 1997; Matheos and Raigemborn, 2012). In its western exposures conglomeratic lenses are common (Furque and Camacho, 1972; Blisniuk et al., 2005). SCF thins to the southeast, from about $600 \mathrm{~m}$ in thickness in the northwest (Ramos, 1979; Blisniuk et al., 2005) to $\sim 250 \mathrm{~m}$ in the southeast (Tauber, 1994, 1997). The gradual transition of marine deposits (Monte León, Estancia 25 de Mayo and El Chacay formations) to the overlying terrestrial deposits of the SCF seems to be slightly diachronous 


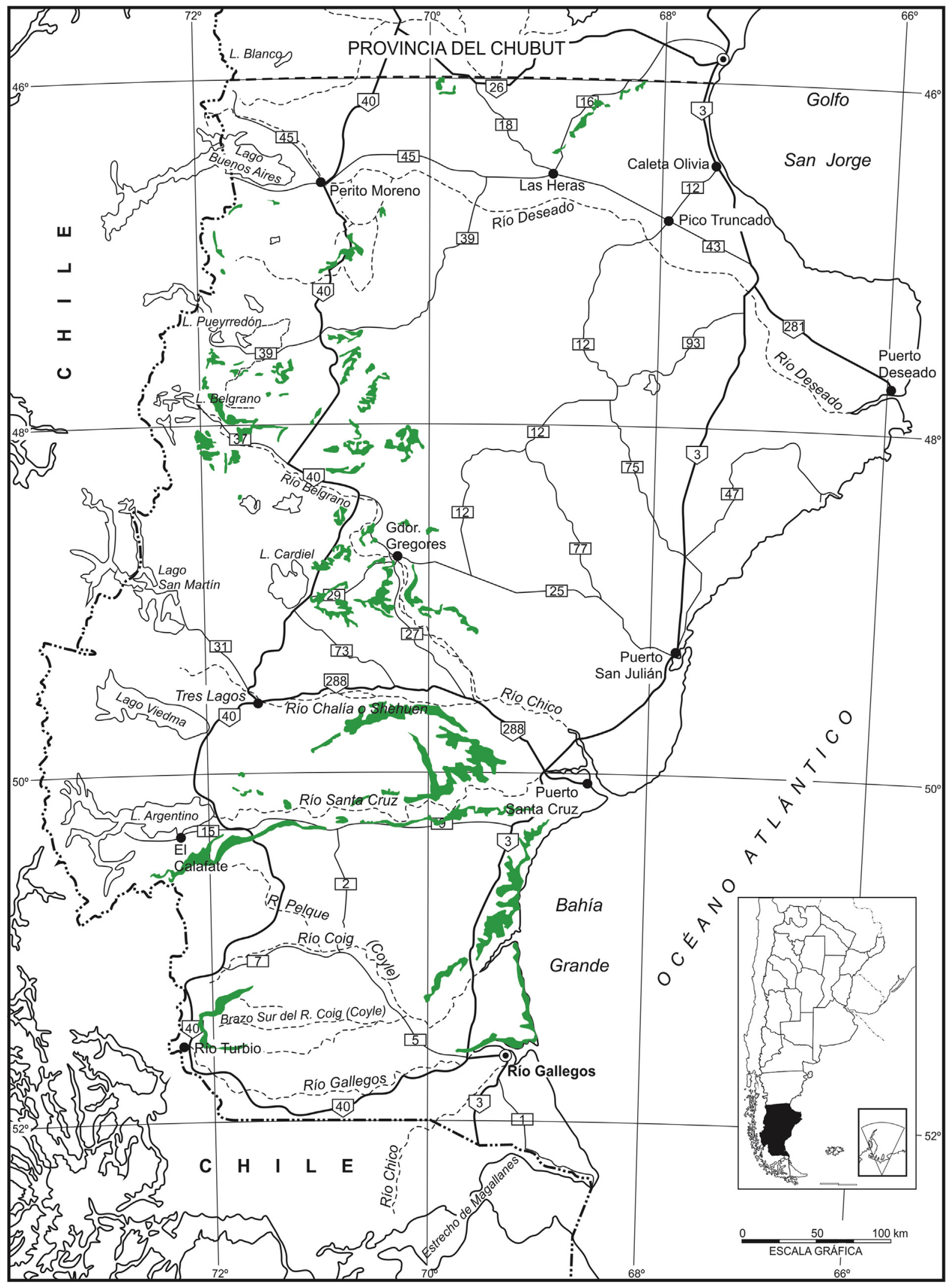

Fig. 1. Outcrops of the Santa Cruz Formation in the Santa Cruz Province. Modified from Vizcaíno et al. (2013). 
along the basin. At the Atlantic coast (SE Santa Cruz province) the top of the Monte León Formation is dated at $18 \mathrm{Ma}$ by means of $\mathrm{Sr}$ isotopes on marine shell carbonate (Parras et al., 2012), and the base of the SCF is dated at $17.8 \mathrm{Ma}$ by the $\mathrm{Ar} / \mathrm{Ar}$ method on minerals from tuff layers (Perkins et al., 2012). To the northwest, near Lago Posadas, Blisniuk et al. (2005) provided a range of 22.5 to $14.3 \mathrm{Ma}$ for the whole column of the SCF using $\mathrm{Ar} / \mathrm{Ar}$ methods from tuff layers. The age of 22.5 Ma was questioned by Perkins et al. (2012) who, based on sedimentation rates and lack of sedimentation breaks, suggested that the base of the unit should not be older than 19 Ma. Perkins' interpretation agrees with the ages obtained at Lago Argentino by Cuitiño et al. (2012), who combining both $\mathrm{Sr}$ isotope stratigraphy and Laser Ablation- $\mathrm{U} / \mathrm{Pb}$ zircon ages from tuff beds, dated the transition of the SCF and the underlying marine beds at $19 \mathrm{Ma}$. These data suggest that the beginning of the deposition of the SCF started earlier in the western region of the Austral Basin than in its eastern region. The age of the complete section of the SCF is well established for the coastal localities from $\sim 18$ to 16 Ma (Perkins et al., 2012). Overall, the base of the formation rests conformably on marine deposits of the Monte Leon Formation and its equivalents (Feruglio, 1938; Cuitiño and Scasso, 2010; Griffin and Parras, 2012).

The best known SCF exposures, especially noted by their fossil vertebrate richness, are located to the southeast along the Atlantic coast (Feruglio, 1949; Marshall, 1976; Tauber, 1994, 1997; Vizcaíno et al., 2012a), whereas less intensively studied outcrops appear along the Andean foothills, from the Río Turbio area in the south, to the Lago Posadas area in the north (Marshall, 1976; Nullo and Combina, 2002; Blisniuk et al., 2005; Bostelmann et al., 2013) (Fig. 1). Other exposures have received little attention by geoscientists, such as those in the Río Santa Cruz valley, first geologically explored in 1877 by Francisco Moreno (Moreno, 1879). In 1887 Carlos Ameghino made the first detailed geologic and paleontological reconnaissance identifying fossiliferous localities and producing the information up on which his brother Florentino Ameghino (1889) based his Formación Santacruceña and Piso Santacruceño (Santacrucian stage). Later, F. Ameghino (1900-1902) divided the Piso Santacruceño in a younger étage Santacruzienne and older étage Notohippidéen (Notohippidian stage). Currently, the Notohippidian is regarded as representing early Santacrucian local fauna (Marshall and Pascual, 1977; Marshall et al., 1983).

Over the ensuing years, more widely exposed and accessible highly fossiliferous exposures of SCF have taken priority in the paleontological literature, so much so that C. Ameghino's Río Santa Cruz discoveries (upon which the faunal content of SCF was originally based) passed into a sort of oblivion. In the classic summary of the Santacrucian localities, Marshall (1976) mention these important localities only collectively as Barrancas del Río Santa Cruz and in a recent expanded abstract Tauber et al. (2008) report several paleontologic sites, without making a precise identification with the C. Ameghino's localities (see below).

Based on historical information and several of our own expeditions to the Río Santa Cruz since 2009, Fernicola et al. (2010, 2013) gave a preliminary report on the geographic location of $C$. Ameghino's (1887) fossiliferous localities. The goal of this contribution is to further establish the geographical locations of the 1887 localities, formalize their names, and evaluate the stratigraphic position of the mammal-bearing levels. Also, we review the geographic provenance of the species that F. Ameghino used to establish the Notohippidian stage.

\subsection{Historical context}

The goals of the early explorations of the Patagonian region during the XIXth century, made by expeditions of FitzRoy, Darwin and Sulivan were much broader than geologic and paleontological, including general issues on geography and natural history (Brinkman, 2003; Fernicola, 2011a,b; Vizcaíno et al., 2012b, 2013). The first expedition with specific geologic and paleontological purposes was launched in 1886 by, Moreno and Florentino Ameghino, Director and Sub Director of the Museo de La Plata, respectively. They commissioned Carlos Ameghino, then preparator of paleontology at the Museo de La Plata to explore the Río Santa Cruz (Farro, 2008, 2009; Podgorny, 2009; Fernicola, 2011a, b; Vizcaíno, 2011; Vizcaíno et al., 2012b, 2013). Maps produced by FitzRoy and extended and improved by the expedition of Moreno of 1876-77 served as a guide for the Ameghino expedition, which began in January 1887 and returned to La Plata in September 1887 with more than 2000 fossil pieces (F. Ameghino, 1887; C. Ameghino, 1890). Many of the fossils were quickly studied and reported by Florentino in a concise paper, in which he recognized 122 taxa, of which 110 were new species (F. Ameghino, 1887). Ameghino intended that the new taxa would be more extensively described and figured in a later contribution. For different reasons, however, Moreno and F. Ameghino could not agree about where to publish the fossil collection of 1887 (Fernicola, 2011a). This, together with a contentious prior relationship that existed between both (Podgorny, 2009), resulted in the departure of F. Ameghino from the Museo de La Plata on February 25, 1888 (F. Ameghino, 1889; Fernicola, 2011a,b). This separation exacerbated the conflict on how the fossils should be published and prompted a vigorous competition for obtaining new fossils from Santa Cruz. In November 1888, Moreno sent Santiago Pozzi and Clemente Onelli on a new museum expedition to the Río Santa Cruz (Moreno, 1890; Farro, 2009; Fernicola, 2011a,b; Riccardi, 2008; Vizcaíno et al., 2012b, 2013). Meanwhile, F. Ameghino, who had misappropriated part of the 1887 collection intended originally for the Museo de La Plata (Fernicola, 2011b), prepared the manuscript of his extensive "Contribución al Conocimiento de los Mamíferos Fósiles de la Argentina” (F. Ameghino, 1889), in which he described all known fossil mammals of Argentina including those of Río Santa Cruz (F. Ameghino, 1889). As mentioned above, in that article Ameghino (1889) based his Piso Santacruceño mainly on the lithological and faunal composition of the sites in the Río Santa Cruz valley. Based on this concept Pascual et al. (1965) formalized the "Edad Mamífero Santacrucense" (Santacrucian Land Mammal Age).

C. Ameghino (1890) stated that he discovered three separate fossil-bearing outcrops on each margin of the Río Santa Cruz, between 90 and $200 \mathrm{~km}$ west of its mouth. However, in a letter sent to his brother in 1887 from Santa Cruz (Letter 166 published in Torcelli, 1935) and in his Travel Diary of 1887 (published by Rusconi, 1965) he mentions a fourth locality, about $50 \mathrm{~km}$ further southwest than those mentioned in the 1890 publication. In March 1889, C. Ameghino was also dismissed from the Museo de La Plata, and in September of the same year he returned for a second time to the Río Santa Cruz to prospect on the river, up to Lago Argentino (F. Ameghino, 1906; Rusconi, 1965; Vizcaíno, 2011). A month later, Moreno sent a third museum expedition headed by Juan Ivovich and Francisco Larumbe to Santa Cruz (Moreno, 1890; Farro, 2009; Riccardi, 2008; Vizcaíno et al., 2013). The competition in Santa Cruz between Moreno and the Ameghino brothers was to continue until the early 1890s (Vizcaíno et al., 2012b, 2013). One positive result of this competition was the discovery of many new paleontological localities along the Atlantic coast between Monte León and Río Gallegos. The Atlantic outcrops are more extensive and yield more complete specimens than those from the Río Santa Cruz (Marshall, 1976; Vizcaíno et al., 2012a). The specimens from these new localities were announced by F. Ameghino (1890, 1891, 1894) and Mercerat (1890a-c, 1891a-f) who had replaced Ameghino in the Department of Paleontology at the Museo de la Plata from 1890 to 1892 . 


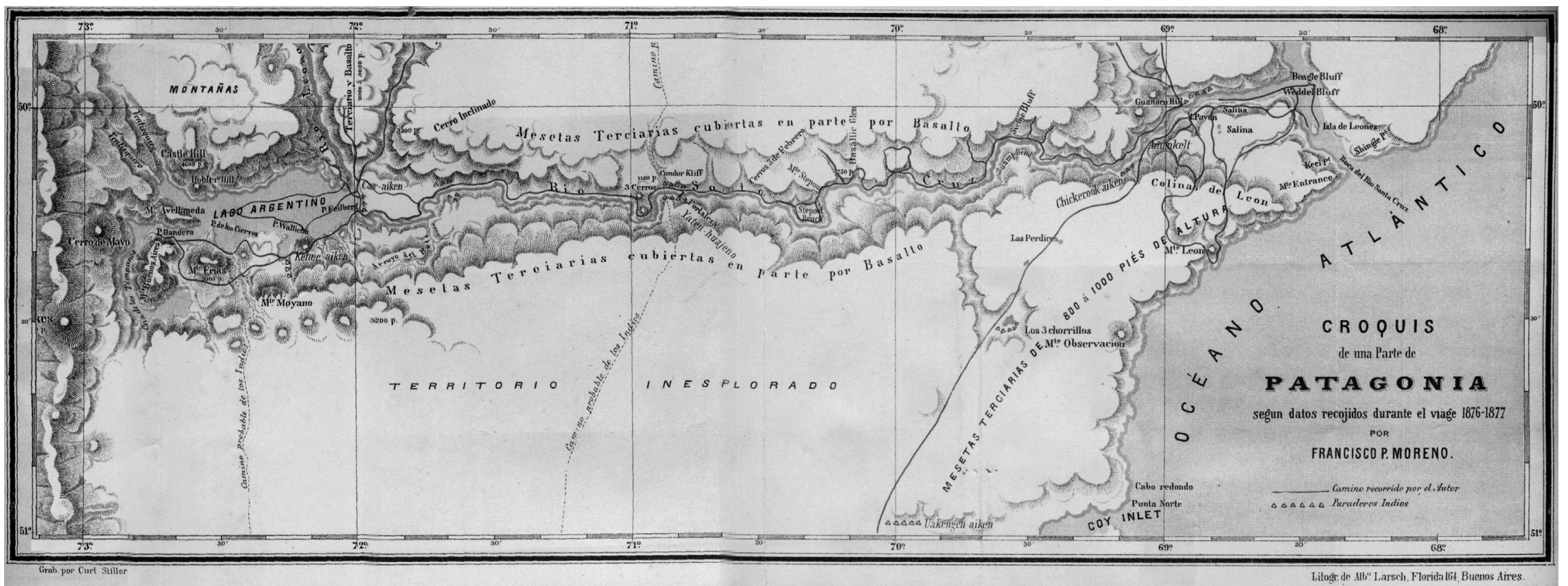

Fig. 2. Map of the Río Santa Cruz with the itinerary and localities of the expedition of Francisco P. Moreno in 1876-77. Modified from Moreno (1879). 


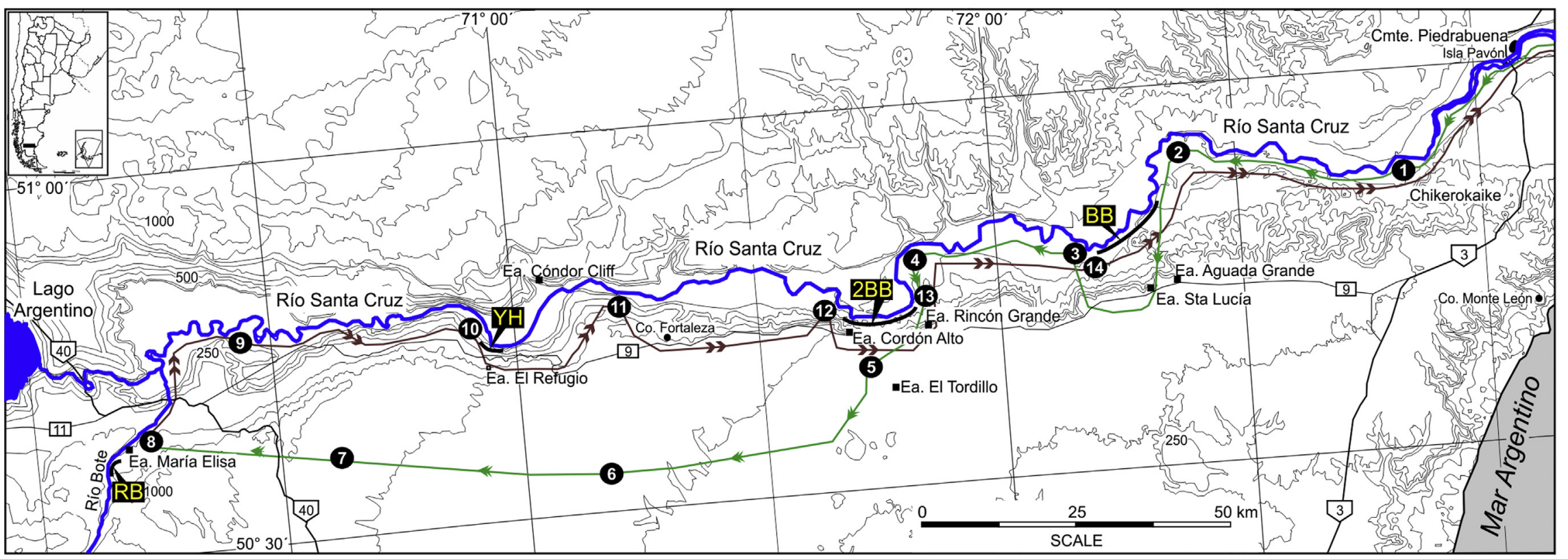

Fig. 3. Map of the Río Santa Cruz area with the itinerary of the expedition of Carlos Ameghino in 1887, based on Carlos Ameghino's Travel Diary and the map of the Río Santa Cruz published by Moreno in 1879 (Fig. 2). Brown line

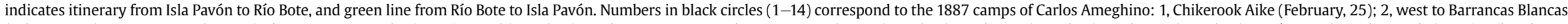

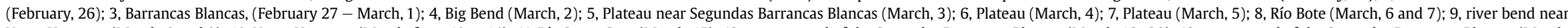

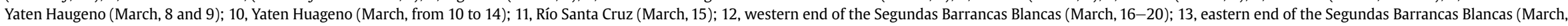

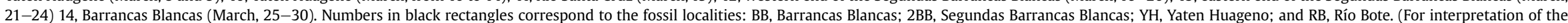
references to color in this figure legend, the reader is referred to the web version of this article.) 
The quality of the specimens described and the novel and contentious evolutionary hypotheses developed by F. Ameghino in his publications sparked a desire among several foreign scientists from Europe and North America to obtain Santacrucian fossils. These was achieved via direct purchase, exchange, and/or through their own expeditions (Podgorny, 2009; Vizcaíno et al., 2012b, 2013). The well-known quality of the fossils from sites on the Atlantic coast lead to the virtual abandonment of sites on the Río Santa Cruz, a phenomenon that continued throughout the twentieth century (Vizcaíno et al., 2012a, 2013). The localities of the Río Santa Cruz were so neglected that Marshall et al. (1983) recognized a coastal site, Monte Léon (Figs. 1-3), as the type locality of the Santacrucian Land Mammal Age, even though this concept is based on the faunal assemblage that F. Ameghino (1889) described from sites along the Río Santa Cruz. The same happened with the historical sources used in subsequent biostratigraphic work that included the Santacrucian fauna, in which only the paper of $C$. Ameghino (1890) and/or subsequent papers of F. Ameghino (1900-1902, 1906) were considered, and the mammal-bearing exposures on the Río Santa Cruz were only mentioned in general terms (e.g., Marshall et al., 1983; Tauber et al., 2008). For instance, in the list of Santacrucian localities Marshall (1976) included "Barrancas del Río Santa Cruz" as an undetermined number of exposures situated mainly in the middle part of river. Furthermore, pertinent information available in the posthumously published letter and Travel Diary of C. Ameghino (see above) was excluded and consequently the report of the westernmost locality being near Lago Argentino, impeded identification of the geographical source of the specimens on which F. Ameghino established the faunal lists of his Santacrucian and Notohippidian stages (e.g., González and Scillato-Yané, 2009). The latter Notohippidian was formalized by F. Ameghino (1900-1902) as the oldest Santacrucian subdivision, the type locality of which was in the Car-Aiken or Kar-Aiken region, located northeast of Lago Argentino (Fig. 2) although Marshall and Pascual (1977) did suggest that F. Ameghino $(1902,1906)$ included in his Notohippidian some taxa based on specimens collected in other sites not enumerated.

\section{Materials and methods}

As already mentioned three main historical sources used here were published in the reverse order to the actual time when their were elaborated: 1) Carlos Ameghino' Travel Diary was written in 1887 not published until 1965 by Rusconi; 2) the detailed letter that Carlos Ameghino sent from Santa Cruz to his brother Florentino in 1887 was not published until 1935 (Letter 166 in Torcelli, 1935); and 3 ) the report of the geological exploration to the Río Santa Cruz of 1887 by C. Ameghino was published by him in 1890 only after being edited by F. Ameghino (Letter 176, in Torcelli, 1935). For the first two sources we had to rely on the transcriptions by Torcelli (1935) and Rusconi (1965). However, it is noteworthy that the spelling and syntax of these transcripts were not always those used by $C$. Ameghino in his manuscripts.

The geographical references used here correspond to those present in the historical sources mentioned, which are based on the map of the Río Santa Cruz published by Moreno in 1879, and its antecedent map published by FitzRoy (1837). All historical references regarding the locations of the Río Santa Cruz, mentioned in the text, were confirmed by our field observations since 2009 along Río Santa Cruz and near Lago Argentino. For precise positioning of each locality and stratigraphic measurements we used the topographic charts of the Instituto Geográfico Nacional (Argentina) at 1:100,000 scale and Global Positioning System device (GPS). For sedimentary section measurements we used a Jacob's Staff. The translations of C. Ameghino's account into English takes into account modern grammar and syntax but are otherwise as they are published.

\section{Three stories of a field trip}

\subsection{Account 1: Carlos Ameghino' travel diary of 1887}

\subsubsection{First visit to Barrancas Blancas (February 27-March 1)}

Carlos Ameghino and his assistants, Ataliba and Francisco, left from the Government House of Santa Cruz, on February 21, 1887. They arrived on the 25th to the Indian settlement Chikrokaiken (in Rusconi, 1865: 36; =Chikorkaik of C. Ameghino, 1890: 8; =Chickerook-aiken of Moreno, 1879: 241; Fig. 2). On the 26th, they continued their journey to the west and camped a short distance from Barrancas Blancas. In his entry of February 27th he says: “... We left early and walked along the river bank, but there came a moment when it is necessary to deviate, when the river takes the eastern end of the Barrancas Blancas leaves only an impracticable narrow path ... We climbed to the high plateau and reached the opposite end of the cliff. When we arrived there we were forced to descend ... we immediately headed to the river, which runs about $1 \mathrm{~km}$ from the cliffs, where we made camp on a beautiful little valley ... Walking along its bare flanks, I had the fortune to discover some interesting remains of fossil animals, the first of terrestrial origin that I had collected on this trip". Between the February 27 and March 1, Ameghino mentioned that he collected xenarthrans, notoungulates, marsupials, and rodents. Before continuing to the west, he spent the afternoon of March 1 “... arranging the collections obtained, and burying the heaviest portion at the bottom of a bush to collect it on the way back...".

\subsubsection{First visit to Segundas Barrancas Blancas (March 3)}

After breaking camp, Ameghino continued to the west: "Day 2 [March 2] ... we always walked along the river edge, as we moved, the immense 'Barrancas Blancas' gradually disappeared on the horizon [behind us]... The Barrancas Blancas disappeared from our sight, and only some arid hills can be seen in the direction from which we passed ... At about 5 pm we camped in the corner of a big bend that the river forms from south to north, and then to the east. From here, we observed a system of bare cliffs of similar structure to those that we have just left, and that by analogy I will call 'Segundas Barrancas Blancas'. On March 3, he wrote: “... we broke camp, and continued our trip. As the path in this great bend was extremely rugged, and does not allow passage without serious danger, I decided to climb up to the plateau. Crossing deep and treacherous gorges, I managed to reach the first bare small hills, and here I again focused on the search for fossils, with such a success that judging by the many pieces collected in the short time at my disposal, these cliffs should be immensely rich in objects of this nature". Among the pieces found by Carlos Ameghino, he only mentioned the presence of the ungulate Astrapotherium.

\subsubsection{Nearby Río Bote (March 7)}

Carlos Ameghino continued his journey to the west: "Day 4 [March 4] ... we traversed the plateau because it was more expeditious and less rugged... In the afternoon we saw, for the first time, the Cordillera on the far western horizon... Day 5 [March 5].... Early we left this place ... after long, long hours of wandering in this inhospitable region... We crossed a chain of black basalt hills on the north and we arrived to our happiness in a valley in which the abominable basalt margin ends... Around 5:30 pm we reached the edge of a very high plain, from where we saw the magnificent Río Santa Cruz, and farther to the west an inland sea: the beautiful Lago Argentino ... trying to get to the river would be useless [at this point], because it was still at least a couple of leagues [about $10 \mathrm{~km}$ ] 


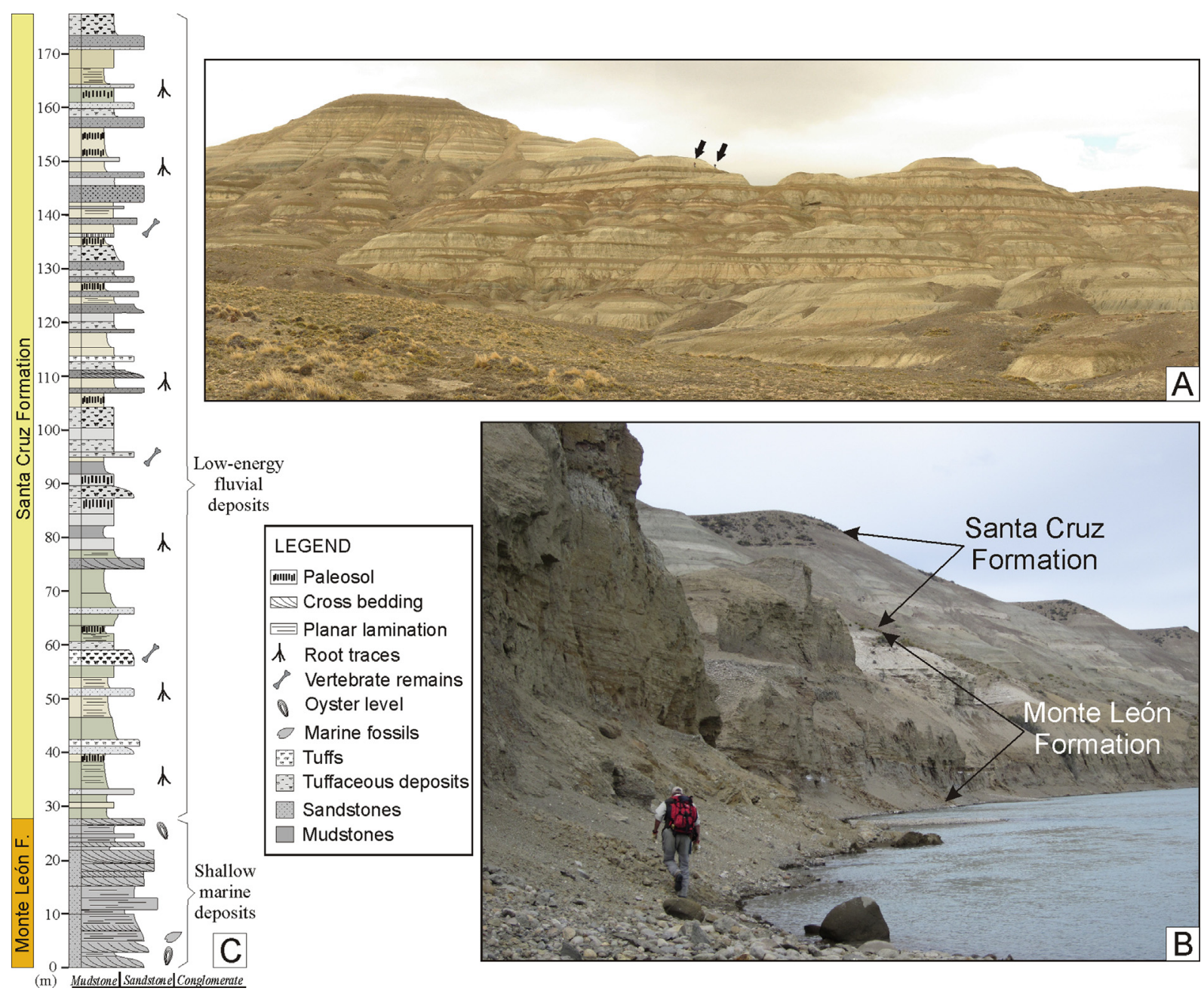

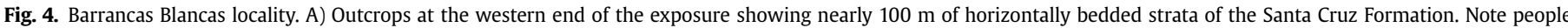

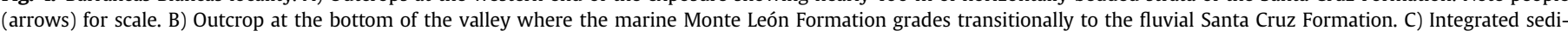
mentary $\log$ of both locations pictured in A and $\mathrm{B}$

from us ... On the way, we had noted a small lake about 5 blocks [approximately $750 \mathrm{~m}$ ] from here, which might supply the necessary water for the night. Without wasting time we left for that place ... Day 6 [March 6]... We saddled and at 8 am started our journey westwards along the side of the plain and descending into the valley. Some bare cliffs can be seen in the distance in that direction, which I want to reach today... At about $3 \mathrm{pm}$ shortly before [reaching] the bare cliffs, we arrived at a canyon that trends south where we found splendid green pastures with high grass that reach the belly of the horses. Moving to the bottom of the cliff we found a magnificent spring ... Day 7 [March 7]... I picked up some fossils but almost all identical to those collected in the lower course of the river ... On returning to the camp, I climbed to the plain to see the lake, but closer now". On March 8, with the arrival of a snowfall, Ameghino decided to return.

\subsubsection{Yaten Huageno (March 10-14)}

On March 8 and 9 they camped again near to Río Santa Cruz. On March 10 Ameghino wrote: “... we arrived to a place where the river makes an immense and sharp bend descending almost at a right angle from north to south, before running to the east. As far as I can tell, the Indians call this place Yaten Huageno ... in the corner of this sharp bend there are some colossal bare cliffs which resemble enormous forts ..." In these deposits, he collected xenarthrans, notoungulates, and rodents. They departed on March 14 moving eastward "...to avoid the detours formed by the river to the north, where one can observe immense gorges and basalt cliffs that make this route impassable. This impressive corner is fairly called 'La Fortaleza'...” (Fig. 3).

\subsubsection{Second visit to Segundas Barrancas Blancas (17-21 March)}

On March 16, they camped on the western margin of "Segundas Barrancas Blancas", and on March 21 they camped at the eastern end of this cliff exposure. Between March 17 and 21, Ameghino collected many fossils. Bad weather from March 22 and 23 prevented him from continuing his work, so the 24th, he prepared his equipment to leave the next day.

\subsubsection{Second visit to Barrancas Blancas (March 26-30)}

On March 25, at 6 am he moved towards Barrancas Blancas, arriving at $4 \mathrm{pm}$ at the place where he had camped on the outward journey and buried part of the collection. Between March 26th and 29th, he collected additional fossil mammals specimens. On March 30, he mentions the discovery of marine beds: "Exploring the extremity of the cliffs I have made an interesting discovery today I have observed that below the subaerial [stratigraphic] levels, which contain terrestrial fossils, there are well developed sea beds, with wide banks of oysters and other marine fossils" (Fig. 4). On March 
31 they left Barrancas Blancas, arriving at Government House on April 3, 1887.

\subsection{Account 2: letter sent by Carlos to his brother of May 6, 1887}

In his letter of May 6, 1887 to Florentino, Carlos wrote: “Our first camp after we left Pavón Island to the west was in a place that the natives call Chikrok-kaiken (Fig. 2) ... the next day ... we continued our trip, and we camped ... a short distance from Basalt-Glen (Fig. 2), where there are immense cliffs, which the natives call 'Barrancas Blancas' ... I made my first findings [of fossils] ... We left this place on March 2, and in order to gain time and way, we left the rugged valley of the river for the flat plateau, and after five consecutive days of riding on the Pampa, we caught sight of Lago Argentino on the evening of March 6. Here I spent a day, busy in exploring a cliff, where I collected some fossils, but almost all of which are similar to those already found in the lower course of the Río Santa Cruz. On March 8, we started to descend the river ... The richest site I have visited, is located three days away from the Lago Argentino, in a place that the Indians know as Yaten Huageno. I have found fossils along the whole course of the river, wherever there are bare cliffs, and at all levels of Formation ... In one of these cliffs (Barrancas Blancas), found four days ride from of the Government House... I found below the strata which contain fossil remains of terrestrial animals, a well developed marine terrain with strong banks of oysters and other marine fossils, strata alternating with whitish sandy clay stratified beds ...".

\subsection{Account 3: geological explorations in Patagonia, Carlos Ameghino 1890}

C. Ameghino (1890) related that on February 26 they left the Indian place called Chikorkaik to continue westward to the place called Barrancas Blancas, located “... at the western end of the immense bend that the river described in Swamp bank [=Swamp Bend of FitzRoy, 1837 =Suamp Bend of Moreno, 1879] or Rincón Grande" (Figs. 2 and 3). In these deposits, he reported collecting cingulates, sloths, notoungulates, marsupials, and rodents in the upper strata and that "The lower basal strata of the cliff is occupied by a marine formation...".

On March 2 he commented “... We have decided to leave Barrancas Blancas, to ascend the river before the snow season begins, we left the rugged river valley and we climbed to the plateau to continue our interrupted trip to the interior". Carlos mentioned that on March 6 “... after crossing the last tributaries of Río Bote, we camped for the afternoon in the surroundings of the beautiful Lago Argentino. There, I was planning to stay for a few days and explore the vicinity of the lake, but the next day we were surprised by heavy snow, and we were forced to return". On March 8, they started the trip back “... along the river, I was fortunate to discover two new fossil sites ... The first ... is located three days ride on the return from the lake, in the large cliffs a short distance from YatenHuageno, on a considerable bend the river makes at this point." Carlos Ameghino mentioned that he collected cingulates, notoungulates, rodents, and astrapotheres at Yaten Huageno.

According to Carlos, "The second site is located at approximately $42 \mathrm{~km}$ downstream from Yaten Huageno, shortly before the Basaltic Glen canyon, at the apex of a great bend where the turns southeast, then bends sharply to the north to resume its interrupted course in the east. In this site ... I found the first remains of Pachyrucos..." Finally, Carlos mentioned that "After visiting the interesting Barrancas Blancas site with the same or better result as the first time, we arrived on April 1 to the Isla Pavón, and 3 of this month [April 3], we returned to the Government House, after one month and 12 days of profitable absence".

\section{Results}

Combining data from these three accounts with our field work since 2009 along the Río Santa Cruz, and in the area nearby to Lago Argentino, allowed us to locate precisely the four fossil sites mentioned by Carlos Ameghino variously in his three accounts and to recognize the general stratigraphy of the area.

\subsection{General stratigraphy}

The valley of Río Santa Cruz forms a prominent incision into the Neogene sedimentary cover of the Austral (or Magallanes) Basin. The E-W oriented valley contrasts with the smooth topography of the plateaus (mesetas) that surround it, especially to the south (Meseta Pampa Alta, Strelin et al., 1999; and Pampa de Monte León, Panza, 2002). The oldest unit recognized is the Early Miocene marine Monte León Formation (Parras et al., 2012), that is restricted to the east and to the topographically lower portion of the Río Santa Cruz valley. Conformably and transitionally overlying the Monte León Formation is the terrestrial SCF, which the best outcrops appear along the southern slope of the valley. The estimated thickness of SCF in the valley is $250 \mathrm{~m}$, although our observations are confined to the well exposed first 100 basal meters from the base. At its western end, the valley broadens and becomes a colossal glacial trough with Lago Argentino at its apex (Strelin et al., 1999). There, older units crop out due the Neogene Andean uplift. Throughout its course on the river, the SCF is covered unconformably by late Miocene-Pleistocene sedimentary deposits of fluvial and glacial origin and by Plio-Pleistocene basaltic lava flows (Strelin et al., 1999; Panza, 2002). In the western portion of the valley, the late Cenozoic sedimentary cover is composed of a complex assemblage of glacial, fluvial and lacustrine sediments (Strelin et al., 1999). To the east the cover consists of well-sorted fluvial gravels of the terrace systems associated to the valley formation history (Panza, 2002). The basaltic lava flows are found along both sides of the central and western parts of the valley (Panza and Franchi, 2002), such as the Cóndor Cliff Basalt (Strelin and Malagnino, 2009).

\subsection{Fossil localities}

Below we discuss the information compiled and give the location and names of the fossil sites. These are referenced to the names of the ranches (estancias, abbreviated as Ea.) that today contain them.

\subsubsection{Barrancas Blancas (=Ea. Santa Lucía - Ea. Aguada Grande)}

According to the above accounts this site is located to the west of the Indian settlement Chickerook-Aike (Fig. 2: Moreno, 1879). In 1890 , Carlos Ameghino provided more precise information to place Barrancas Blancas “.... at the western extremity of the great bend described by the river in Swamp-Bank [=Swamp Bend of FitzRoy, 1837 =Suamp Bend Moreno, 1879] or Rincón Grande...”. These geographic references coincide with those that Carlos stated in his letter to Florentino, noting that Barrancas Blancas is located to the east of Basalt Glen (Fig. 1). During our exploration between Basalt Glen and Swamp Bend, we observed badlands exposures of pale horizontal strata approximately $6 \mathrm{~km}$ in length from east (S $50^{\circ} 9^{\prime} 38.31^{\prime \prime}-\mathrm{W} 69^{\circ} 40^{\prime} 23.40^{\prime \prime}$ ) to west (S $50^{\circ} 12^{\prime} 31.70^{\prime \prime}-\mathrm{W}$ $\left.69^{\circ} 43^{\prime} 10.66^{\prime \prime}\right)$. The eastern end of this exposure is located in Estancia Aguada Grande whereas the western end is located in the Ea. Santa Lucia (Topographic Chart Estancia Santa Lucia, 5169-2). Our stratigraphic observations correspond to what Carlos Ameghino described. Two distinctive sections can be recognized within this exposure (Fig. 4). A lower marine section of $30 \mathrm{~m}$ in thickness crops 
out at the eastern end of the exposure where the river erodes the slope. This section bears sparse marine bivalves, gastropods and barnacles, and beds of Ostrea (?) cf. hatcheri (Miguel Griffin com. pers. 2010) are noticeable (Fig. 4). We preliminarily assign this section to the upper part of the Monte León Formation. It is covered transitionally by the upper section which is assigned to the Santa Cruz Formation, composed by nearly $100 \mathrm{~m}$ of well stratified, yellow to greenish siltstone and tabular claystone beds, with evidence of paleosol formation. Sandstone beds are infrequent and abundant pyroclastic material is observed mixed with the epiclastic material, as well as thick tuff beds (Fig. 4).

The upper section (Santa Cruz Formation) contains fossil vertebrates, mostly mammals, among which we recognized cingulates (Propalaehoplophorus sp., Proeutatus sp, Prozaedyus sp. and Stenotatus sp.), sloths (Hapalops sp.), rodents (Acaremys sp. and Neoreomys sp.), notoungulates (Nesodon sp. and Adinotherium sp.), litopterns (Thoatherium sp.), astrapotheres (Astrapotherium sp.), marsupials (Palaeothentes sp.), and primates (Homunculus sp.).

\subsubsection{Segundas Barrancas Blancas (=Ea. Cordón Alto - Ea. El Tordillo - Ea. Rincón Grande)}

This locality was omitted in the letter that Carlos Ameghino sent to his brother Florentino on May 6, 1887. However, his Travel Diary mentions that he found an important fossiliferous site, which he informally called Segundas Barrancas Blancas, located West of Barrancas Blancas and East of Yaten Huageno (Fig. 2). Carlos did not use that name in his 1890 publication, but he gave further geographical details to locate this fossiliferous locality slightly West of Basalt Glen and about $45 \mathrm{~km}$ East of Yaten Huageno (Fig. 2). The different geographical references of the three accounts are complementary. We locate an extensive outcrop of about $14 \mathrm{~km}$ in length from East (S 50 $16^{\prime} 12.48^{\prime \prime}-\mathrm{W} 70^{\circ} 22^{\prime} 23.21^{\prime \prime} \mathrm{W}$ ) to West (S $\left.50^{\circ} 16^{\prime} 51.90^{\prime \prime}-\mathrm{W} 70^{\circ} 17^{\prime} 54.76^{\prime \prime}\right)$. The western end of this exposure is located at Ea. Cordón Alto, while the eastern end is at Ea. Rincon Grande (Topographic Chart Estancia La Barrancosa, 5169-1). The exposures lie at the bottom of the valley, where the river erodes its southern slope. Here, SCF is composed of $90 \mathrm{~m}$ of horizontal strata of tabular geometry, composed of greenish and yellow siltstones and tabular to lenticular beds of gray sandstones (Fig. 5). Some poor exposures of the Santa Cruz Formation were identified in the uppermost part of the valley slope, giving a total thickness of about $230 \mathrm{~m}$. No marine deposits were observed here.

In this section we found fossil mammal remains, among which we can list cingulates (Eucinepeltus sp., Cochlops sp., Propalaehoplophorus sp., Proeutatus sp., Prozaedyus sp. y Stenotatus sp.,), sloths (Hapalops sp.), rodents (Neoreomys sp., Prolagostomus sp., and Perymis sp.), notoungulates (Nesodon sp., Adinotherium sp., and Interatherium sp.), litopterns (Thoatherium sp), astrapotheres (Astrapotherium sp.), and marsupials (Palaeothentes sp. and Abderites sp.).

\subsubsection{Yaten Huageno (=Ea. El Refugio)}

This locality is mentioned in all three accounts. According to his Travel Diary, is located slightly west of the corner known as "La Fortaleza" and the place called Yaten Huageno (Fig. 2). This last reference was also provided by Carlos Ameghino both in his letter of 1887 and the publication of 1890 . He considered these deposits as the westernmost outcrops located near the Río Santa Cruz (Fig. 3). We located an outcrop of about $2 \mathrm{~km}$ in length from East (S

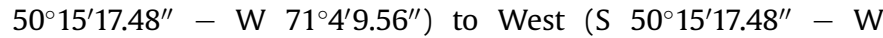
$71^{\circ} 4^{\prime} 9.56^{\prime \prime}$ ) within the lands of Ea. El Refugio (Topographic chart Estancia Cerro Fortaleza, 5172-5) (Fig. 6). This outcrop corresponds entirely to the SCF which lies horizontally, and is composed of $90 \mathrm{~m}$ of brown and greenish siltstone, sandstone and tuff beds. Finegrained beds are tabular and sandstone deposits appear as lenticular bodies (Fig. 6).

We recorded fossil remains of cingulates (Cochlops sp., Proeutatus sp., Prozaedyus sp. and Stenotatus sp.), sloths (Hapalops sp.), rodents (Perymis sp. and Neoreomys sp.), and notoungulates (Nesodon sp. and Interatherium sp.).

\subsubsection{Río Bote (=Ea. María Elisa)}

The location of this paleontological site is the most contentious of the four visited by Carlos Ameghino in 1887, because it was not included in his publication of 1890 . However, Carlos reported the existence of this site in his Travel Diary, and in his letter to

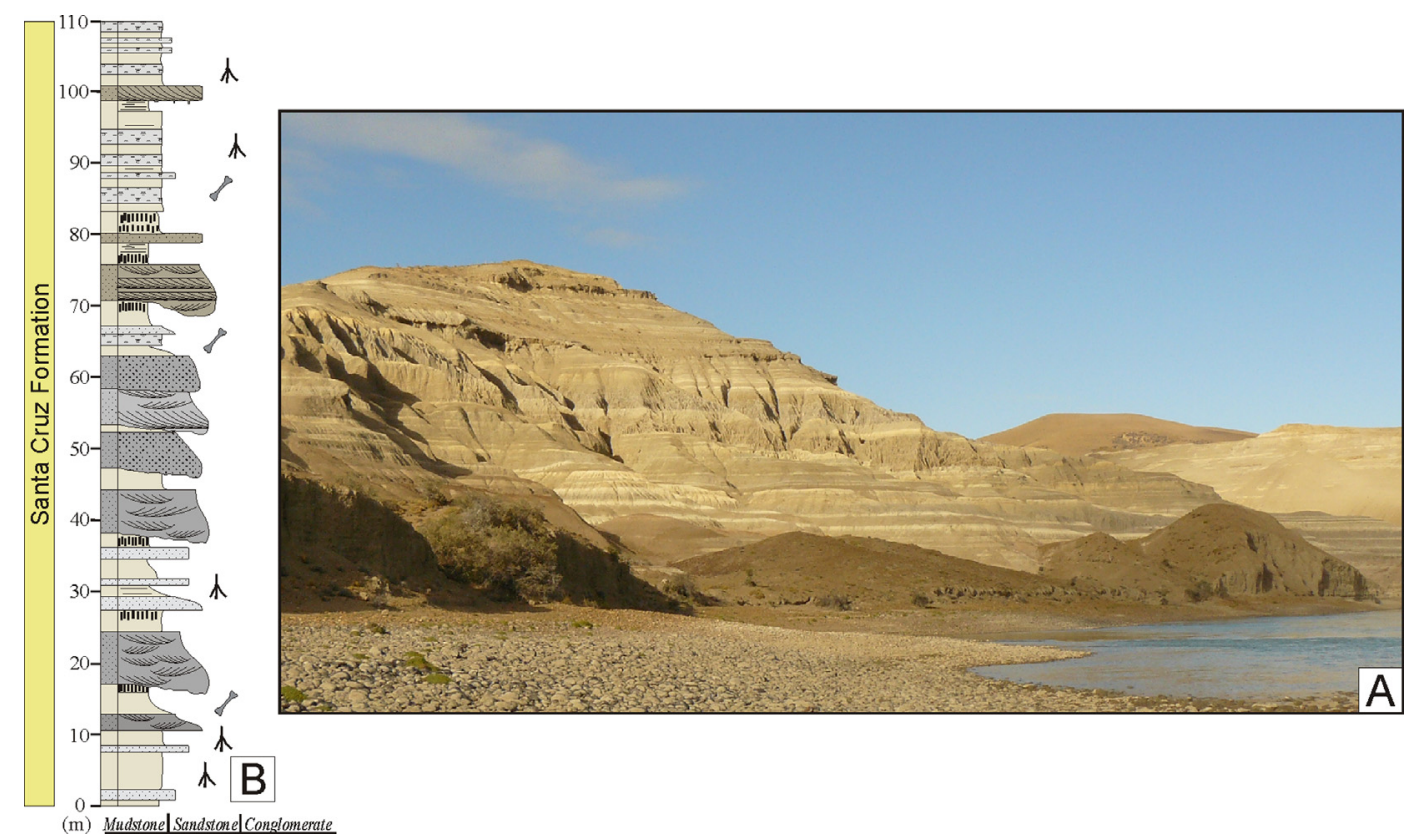

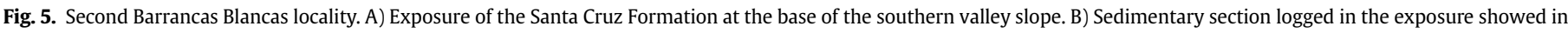
A. Legend as in Fig. 4. 

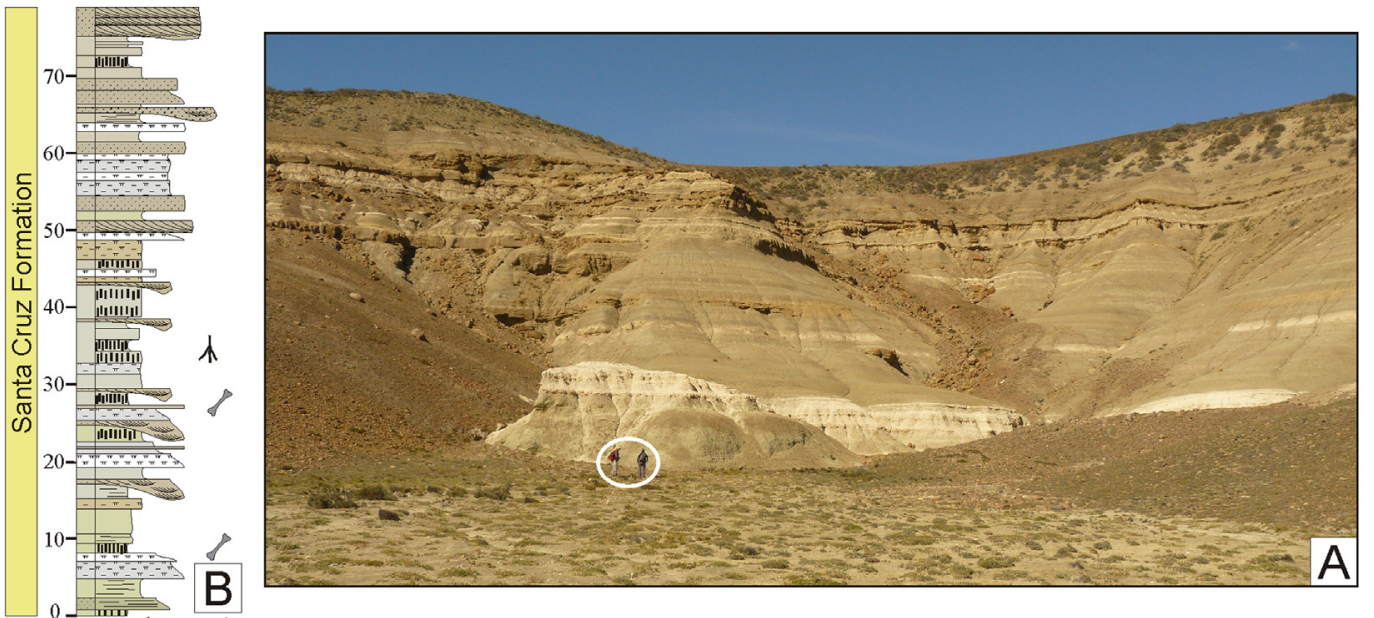

(m) Mudstone| Sandstone Conglomerate

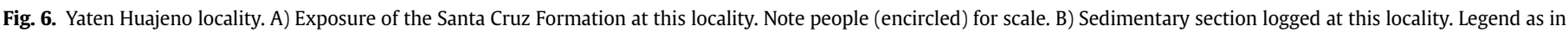
Fig. 4.

Florentino. Both accounts agree: he noted that on March 7 various fossils were collected and their taxonomic assignment was no different from what Carlos had previously collected in the lower reaches of the valley. In both documents Carlos said that the prospected site is far distant from the Río Santa Cruz. According to his Travel Diary, it is more than $10 \mathrm{~km}$ south of the river, on an extensive cliff oriented south to north, nearby a river that drains into the Río Santa Cruz. These references, together with the data provided in C. Ameghino (1890), that between March 6 and 8 he was around the Río Bote, allowed us to focus our effort on this river. We explored both sides of the Río Bote valley and found an exposure of the Santa Cruz Formation at about $15 \mathrm{~km} \mathrm{SW}$ of it mouth, in the Ea. Maria Elisa (Topographic Chart Estancia La Entrerriana, 5172-10) (Fig. 7). The outcrop is approximately $1.5 \mathrm{~km}$ in length, from northeast ( $50^{\circ} 21^{\prime} 50.31^{\prime \prime}-\mathrm{W} 71^{\circ} 50^{\prime} 14.69^{\prime \prime}$ ) to southwest (S $\left.50^{\circ} 22^{\prime} 27.66^{\prime \prime}-\mathrm{W} 71^{\circ} 50^{\prime} 57.89^{\prime \prime}\right)$ and beds dip a slightly to the east.
In this locality, the base of the Santa Cruz Formation is not exposed, although it can be inferred to be close by, because the underlying marine Estancia 25 de Mayo Formation (Cuitiño and Scasso, 2010) crops out along the Río Bote valley, a few kilometers northeast. According to Cuitiño and Scasso (2010) and Cuitiño et al. (2013) the uppermost marine beds of the Estancia 25 de Mayo Formation (the Bandurrias Member) are covered transitionally by the Santa Cruz Formation. At the Río Bote locality, we measured $125 \mathrm{~m}$ of gray to greenish siltstone, sandstone and tuff beds, with minor proportion of conglomerates in lenticular beds. This lithologic array is consistent with the description provided by Furque and Camacho (1972) and Furque (1973) for the lowermost Los Dos Mellizos Member of the SCF at the Lago Argentino region.

At the Río Bote Locality we recorded fossils including cingulates (Proeutatus sp.), rodents (Perymis sp.), and notungulates (Adinotherium sp. and Notohippus sp.).

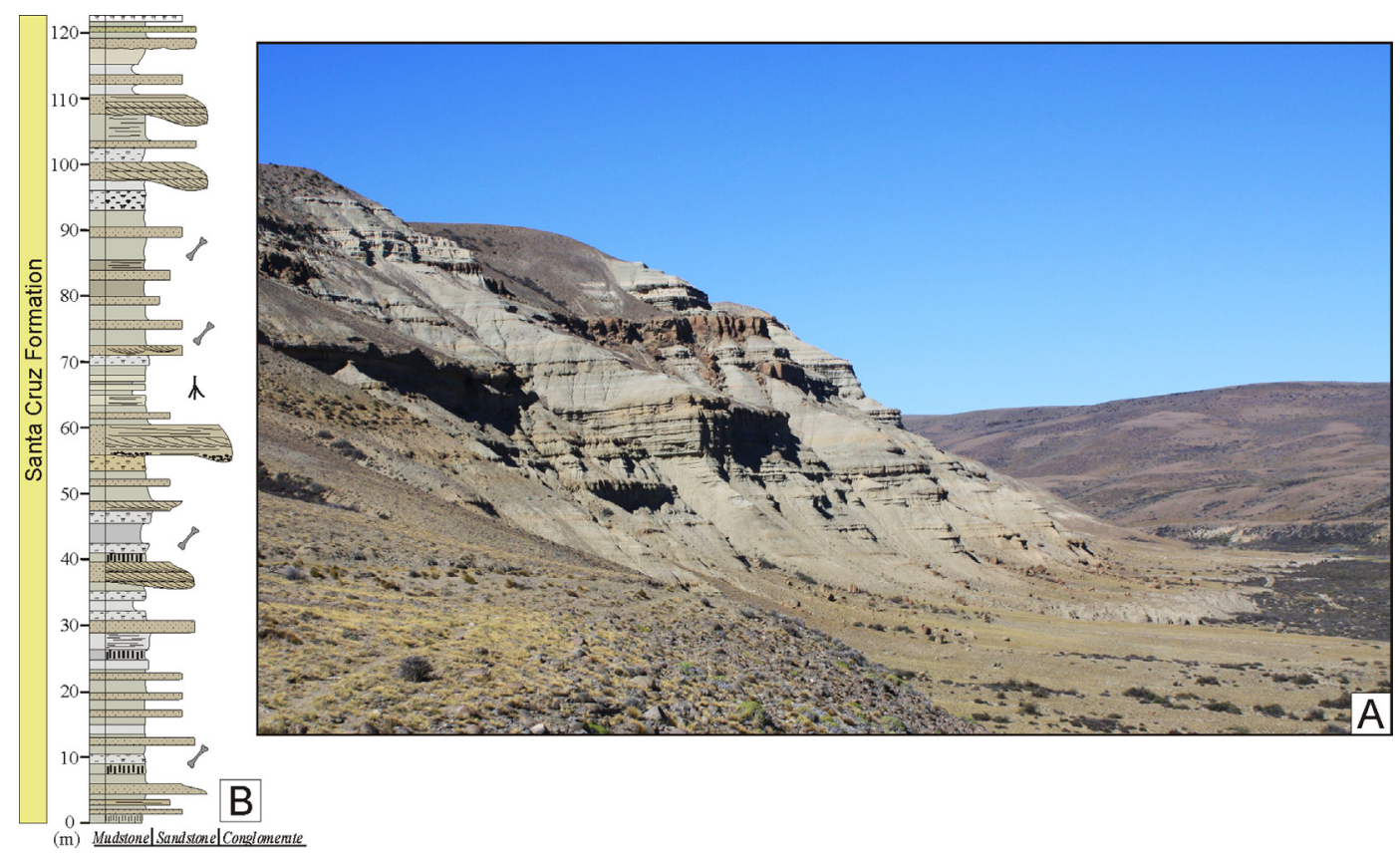

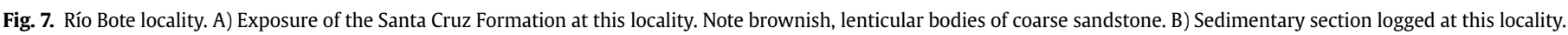
Legend as in Fig. 4. 


\section{Discussion}

\subsection{Stratigraphy}

The field examination of the Santa Cruz Formation in the four localities visited by Carlos Ameghino in 1887 allowed us to make some comparisons regarding the stratigraphy of these mammalbearing beds along the Río Santa Cruz valley. From Barrancas Blancas to Río Bote, the outcrops form an E-W discontinuous belt of nearly $160 \mathrm{~km}$ (Figs. 4-7). The thickness of the exposed individual outcrops is barely above $100 \mathrm{~m}$, although the total thickness of the unit can be inferred to increase from east (about $250 \mathrm{~m}$ at the middle reach of the valley) to west (about $500 \mathrm{~m}$ in the region of Río Bote; Furque, 1973). The studied outcrops would correspond to the basal strata of the SFC. This is clearly visible at Barrancas Blancas (Fig. 4) and near to Río Bote locality (Fig. 7), where the exposures conformably cover the underlying marine units (Monte León and Estancia 25 de Mayo formations, respectively). At Segundas Barrancas Blancas and Yaten Huageno, the base of the SCF is not visible. However, as we could verify in the field, no faulting nor folding affects the horizontal strata of these sections, which together with its position at the bottom of the valley, allows us to assume that the exposures correspond to the lower part of this formation. In this scenario, we conclude that all the observations made by Carlos in his trip were made on the stratigraphically lower beds of the SCF.

From a sedimentological point of view, the four localities are part of a lateral continuous fluvial system, which shows some proximal (western) to distal (eastern) trends. At Río Bote, the locality closer to the Andean belt, the coarsest grain size is recorded, whereas at Barrancas Blancas the grain size is finer. Additionally, the geometry of the sandstone bodies changes from lenticular at western localities to tabular at eastern localities. The base of the unit, visible at Barrancas Blancas and near to Río Bote locality, shows a transition from tide-dominated estuarine systems that grade upwards to a low-energy fluvial system.

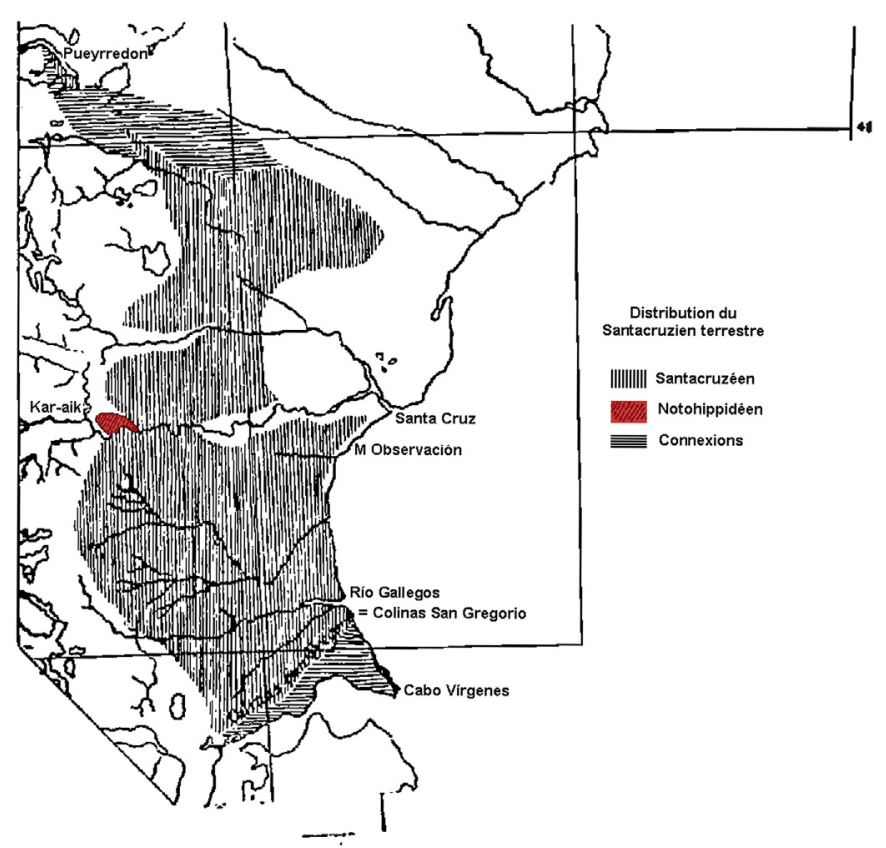

Fig. 8. Map of Santa Cruz Province published by F. Ameghino (1906) shows the distribution of the Notohippidian levels. Modified from F. Ameghino (1906).

\subsection{Paleontological localities}

Comparison among the three accounts summarized above allowed us to identify a set of discrepancies between the versions that the brothers Ameghino decided to publish (C. Ameghino, 1890) and those that were published posthumously (Letter 166 in Torcelli, 1935 and Travel Diary in Rusconi, 1965). Among these discrepancies only two are worth mentioning here. First, in his Travel Diary C. Ameghino recorded that after collecting in Barrancas Blancas and Segundas Barrancas Blancas he went westward across the plateau to attempt to reach Lago Argentino, while in the letter sent to his brother and in his publication of 1890 he mentioned having reached the plateau only after prospecting Barrancas Blancas. Second, Carlos only used the name Segundas Barrancas Blancas in his Travel Diary. However, both discrepancies do not affect the general reconstruction of Carlos trip, nor the possibility of locating the sites prospected by him.

We have now reconstructed the trip itinerary conducted by Carlos in 1887 (Fig. 3) and have established the precise locations of the four fossil localities south to the Río Santa Cruz mentioned in his Travel Diary. The instructions that Moreno gave to the members of the expedition in 1888 to Río Santa Cruz (in Farro, 2008), based on the report that Carlos gave to Moreno when he returned from the 1887 expedition are consistent with our reconstruction. In his 1888 instructions given to Santiago Pozzi and Clemente Onelli, Moreno mentioned four fossiliferous localities on the south bank of the Río Santa Cruz: "Leaving Isla Pavón on the south side, you will arrive at Chikerook-Aiken, where you must examine the place for some days ... and you will study the region geologically with the data of Mr. Ameghino, extending it as much as possible, taking sketches, samples and photographs ... from ChikerookAiken ... you will continue to "Barrancas Blancas", shown in the map, where you will stay as long as you need, so as not to leave any good fossils behind ... We have a chart of the hills in 'Barrancas Blancas', when the terrain allows it, you will go to the great bend of the river in 'Stepout Reach', there is another site [Segundas Barrancas Blancas] ... from 'Stepout Reach', you will continue to 'Yaten Huageno' where you can obtain another collection ... from that point, you will continue to the west until you reach Río Bote; in the high mineral cliffs that are to the south there are undoubtedly fossils ..." (from Farro, 2008). The location of the four localities, agrees exactly with those given by Carlos in his Travel Diary, but not with the publication of C. Ameghino (1890), in which the westernmost paleontological site located in the valley of the Río Bote was omitted. Although at the moment we are unable to establish the reasons that led the Ameghino brothers to do so, it is important to consider that this omission has restricted the understanding of other paleontologists as to the geographical extent of the Santacrucian fauna, as it was defined by F. Ameghino in 1889, solely to the cliffs of the Río Santa Cruz. Thus, in the revision of Miocene fossil localities of Santa Cruz provided by Marshall (1976), the locality in the Río Bote (=Ea. María Elisa) was not mentioned, while the "locality" Barrancas del Río Santa Cruz was recognized in the following general terms: "This locality almost certainly refers to the extensive but discontinuous exposures of Santa Cruz beds along the middle part of the Río Santa Cruz between Lago Argentino and the town of Santa Cruz. The majority of these exposures lies between 75 and $125 \mathrm{~km}$ due E (c. 50 $20^{\prime} \mathrm{S}$, $70^{\circ} 30^{\prime} \mathrm{W}$ ) of Lago Argentino (see Ameghino, 1906; Fig. 57; Feruglio, 1938; Fig. 6)". In this way, according to Marshall (1976) the main exposures would include the localities that Carlos Ameghino called Segundas Barrancas Blancas (=Ea. Cordón Alto Ea. El Tordillo - Ea. Aguada Grande) and Yaten Huageno (=Ea. El Refugio). This scheme was later reproduced by Marshall et al. (1983). 
The westernmost locality, Río Bote (=Ea. María Elisa), provides new evidence on the geographic provenance of the fossil specimens on which F. Ameghino (1900-1902) recognized the species that constituted his Notohippidian list. Briefly, Ameghino (1900-1902) formalized his Notohippidian stage on a set of species that were recognized from fossil specimens that were collected by Carlos Ameghino in 1889, during his third Patagonian expedition, aimed at the west region of Santa Cruz (F. Ameghino, 1900-1902, 1906; Rusconi, 1965; Vizcaíno, 2011). In particular, F. Ameghino (19001902) mentioned "Kar-aiken, north of the Río Santa Cruz, near Lago Argentino, as the locality to observe the typical Notohippidian layers and to collect fossils", while in 1906 he pointed out that "The layers of this stage that appear in Karaiken seem to occupy a considerable extent, and these have a minimum thickness of $80 \mathrm{~m}$. Unfortunately, as I have said, this locality was visited only once in 1889". In this article, F. Ameghino included a map in which the distribution of the Notohippidian levels was restricted to a small region located about $20 \mathrm{~km}$ northeast of Lago Argentino (Fig. 8). However, this information is not consistent with the geographic locations inferred from his taxonomic list of 1900-02. In this list, F. Ameghino (1900-1902) included 72 species, of which 54 were exclusive to the Notohippidian stage. Among the latter, 38 were erected by $\mathrm{F}$. Ameghino after 1890 , while of the remaining 16 Ameghino founded 10 in 1887 and six in 1889. According to F. Ameghino (1887, 1889), 15 of the 16 species were based on specimens collected on the cliff of the Río Santa Cruz. Recently, Fernicola (2011) established that such specimens were found by Carlos on his expedition of 1887. For all these reasons, the specimens of those 15 species (Table 1) that contributed to form the concept for the Notohippidian could not have been collected at Karaiken but must come from some locality samples on the 1887 expedition. The localities in the north margin of the Río Santa Cruz can be discounted because according to the 1887 expedition, the westernmost point prospected by Carlos was Cóndor Cliff, located about $75 \mathrm{~km}$ east of Lago Argentino, almost in front of Yaten Huageno. We propose that the locality in which Carlos collected the Notohippidian specimens corresponds to that not reported by the Ameghino brothers in their lifetime and which we have recognized as Río Bote. It is clear that the inclusion of these 15 species in the Notohippidian list was not a mistake for two reasons. First, F. Ameghino (1900-1902) stated that he had clearly identified the localities where the fossil specimens that he included in the Notohippidian stage were collected. Second, it seems reasonable to consider that such a "mistake" would involve only a few taxa, not such a large number of species.

Table 1

List of the species exclusive to the Notohippidian stage of F. Ameghino (1900-1902) that were founded by F. Ameghino between 1887 and 1889 based on specimens collected by Carlos Ameghino in 1887 expedition, before his first visit to Kar-Aiken made in 1889.

\begin{tabular}{ll}
\hline 1887 & 1889 \\
\hline Marsupial & \\
Microbiotherium tehuelchum & \\
Rodents & \\
Neoreomys indivisus & Perimys procerus \\
Phanomys mixtus & \\
Schistomys erro & \\
Xenarthra & \\
Zamicrus admirabilis & \\
Ungulates & \\
Adinotherium splendidum & \\
Phoberotherium sylvaticum & Icochilus excavatus \\
Planodus ursinus & Icochilus undulatus \\
Protypotherium attenuatum & Patriarchus palmidens \\
Stenotephanos speciosus & Protypotherium claudum \\
\hline
\end{tabular}

The new evidence presented here indicates that the geographic area of the Notohippidian stage is larger than that recognized by F. Ameghino (1900-02, 1906), involving outcrops south as well as north to the Río Santa Cruz, near Lago Argentino. This interpretation is consistent with the proposal of Marshall and Pascual (1977), who argued that the Notohippidian, as a faunal assemblage concept, has a wider geographical distribution than the type locality Karaiken, although they don't mention where else Notohippidian assemblages could be found. Finally, it is not possible at present to exclude that other fossil localities have contributed with different specimens upon which F. Ameghino (1900-1902) built his original Notohippidian list.

\section{Conclusions}

Four, and not three (F. Ameghino, 1889; C. Ameghino, 1890), fossil localities were prospected by Carlos Ameghino in 1887 South to the Río Santa Cruz. From east to west, the first three are on the south bank of the Río Santa Cruz: 1) Barrancas Blancas, 2) Segundas Barrancas Blancas, and 3) Yaten Huageno. The fourth locality, Río Bote is on the eastern bank of Río Bote, a tributary of Río Santa Cruz, south of Lago Argentino. In the four localities we recognized well stratified, fine-grained terrestrial deposits attributable to the Santa Cruz Formation, representing a laterally continuous fluvial sedimentary system. Because the exposures lie at the bottom of the valley, and in some exposures its base is visible, we conclude that the collection of Carlos Ameghino in 1887 was performed in the stratigraphically lower beds of the SCF.

While the eastern three sites were reported in 1890 by Carlos Ameghino, the existence of Río Bote remained obscure because it was only reported in the letter sent to his brother in March 1887, and in his Travel Diary of the 1887 expedition. Thus, the geographical distribution of Santacrucian stage, as it was conceptualized by F. Ameghino in 1889, extends for about $150 \mathrm{~km}$ from east to west, measured from Barrancas Blancas to Río Bote.

F. Ameghino (1900-1902) later transferred from the Santacrucian stage to the Notohippidian stage specimens collected in Río Bote, and the species upon which specimens were based. Thus, the geographic distribution of the Notohippidian stage (sensu F. Ameghino, 1900-1902) is not restricted to Karaiken locality, as he originally claimed, nor to the region north of the Río Santa Cruz near Lago Argentino, but should be extended south of the Río Santa Cruz near that lake, to include Río Bote and probably other outcrops nearby. Hopefully, field work in progress will provide useful information to assert if the claimed faunal differences that define the two stages reflect temporal differences or contemporaneous ecological variants.

\section{Acknowledgments}

We thank the Dirección de Patrimonio Cultural, and Museo Regional Provincial "Padre M. J. Molina” (Río Gallegos, Santa Cruz Province) and Natalia Kovacic, Roberto Díaz, Ariel Ivovich, Alfredo Albertengo, and the Battini family for their hospitality during the field work. We thank especially Néstor Toledo, Verónica Krapovickas, Leonel Acosta, Jonathan Perry, Santiago Hernández del Pino, Laura Chornogubsky, Nahuel Muñoz, and Lauren Gonzalez, for their collaboration during the field works. This is a contribution to the projects: UNLu CCD-CD: 054/12 (JCF) PIP 00781 (JCF), UNLP N647 (SFV), PICT 0143 (SFV), National Science Foundation grants 0851272 and 1348259 (RFK), and National Geographic Society 9167-12 (RFK). 


\section{References}

Ameghino, C., 1890. Exploraciones geológicas en La Patagonia. Bolet. Inst. Geográfico Argent. 11, 3-46.

Ameghino, F., 1887. Enumeración sistemática de las especies de mamíferos fósiles coleccionados por Carlos Ameghino en los terrenos eocenos de la Patagonia y depositados en el Museo de La Plata. Bolet. Mus. La Plata 1,1-26.

Ameghino, F., 1889. Contribución al conocimiento de los mamíferos fósiles de la República Argentina. Actas Acad. Nac. Ciencias 6, 1-1028.

Ameghino, F., 1890. Los Plagiaulacidios argentinos y sus relaciones zoológicas, geológicas y geográficas. Bolet. Inst. Geográfico Argent. 11, 143-201.

Ameghino, F., 1891. Nuevos restos de mamíferos fósiles descubiertos por Carlos Ameghino en el Eoceno inferior de la Patagonia austral. Especies nuevas, adiciones y correcciones. Rev. Argent. Hist. Nat. 1, 289-328.

Ameghino, F., 1894. Enumération synoptique des espéces de Mammifères fossiles des formations Eocènes de Patagonie. Bolet. Acad. Nac. Ciencias Córdoba 13, $259-455$.

Ameghino, F. 1900-1902. L'age des formations sédimentaires de Patagonie. An. Soc. Científica Argent. 50, 109-130, 145-165, 209-229; 51: 20-39, 65-91; 52: 189-197, 244-250; 54: 161-180, 220-249, 283-342.

Ameghino, F., 1906. Les formations sédimentaires du Crétacé Superieur et du Tertaire de Patagonie avec un parallele entre leurs faunes mammalogiques et celles de l'ancien continent. An. Mus. Nac. Buenos Aires 15, 1-568.

Blisniuk, P.M., Stern, L.A., Chamberlain, C.P., Idleman, B., Zeitler, P.K., 2005. Climatic and ecologic changes during Miocene surface uplift in the Southern Patagonian Andes. Earth Planet Sci. Lett. 230, 125-142.

Bostelmann, J.E., Le Roux, J.P., Vásquez, A., Gutiérrez, N.M., Oyarzún, J.L., Carreño, C., Torres, T., Otero, R., Llanos, A., Fanning, C.M., Hervé, F., 2013. Burdigalian deposits of the Santa Cruz Formation in the Sierra Baguales, Austral (Magallanes) Basin: age, depositional environment and vertebrate fossils. Andean Geol. 40 (3), 458-489.

Bown, T.M. Fleagle, J.G. 1993. Systematics, biostratigraphy, and dental evolution of the Palaeothentidae, later Oligocene to early-middle Miocene (Deseadan-Santacrucian) Caenolestoid Marsupials of South America. J. Paleontol. 67 (Suppl. 2), 1-76.

Brinkman, P., 2003. Bartholomew James Sulivan's discovery of fossil vertebrates in the Tertiary beds of Patagonia. Arch. Nat. Hist. 30, 56-74.

Cuitiño, J.I., Scasso, R.A., 2010. Sedimentología y paleoambientes del Patagoniano y su transición a la Formación Santa Cruz al sur del Lago Argentino, Patagonia Austral. Rev. Asoc. Geológ. Argent. 66 (3), 406-417.

Cuitiño, J.I., Pimentel, M.M., Ventura Santos, R., Scasso, R.A., 2012. High resolution isotopic ages for the "Patagoniense" transgression in southwest Patagonia: stratigraphic implications. J. South Am. Earth Sci. 38, 110-122.

Cuitiño, J.I., Ventura Santos, R., Scasso, R.A., 2013. Insights into the distribution of shallow marine/estuarine early Miocene oysters from Southwestern Patagonia: sedimentologic and stable isotope constraints. PALAIOS 28, 583-598.

Farro, M.E., 2008. Historia de las colecciones en el Museo de La Plata, 1884-1906: naturalistas viajeros, coleccionistas y comerciantes de objetos de historia natural a fines del Siglo XIX. Ph.D. thesis. Univesidad de La Plata.

Farro, M.E., 2009. La formación del Museo de La Plata. Coleccionistas, comerciantes, estudiosos y naturalistas a fines del siglo XIX. Prohistoria Ediciones, Rosario.

Fernicola, J.C., 2011a. Implicancias del conflicto Ameghino-Moreno sobre la colección de mamíferos fósiles realizada por Carlos Ameghino en su primera exploración al río Santa Cruz, Argentina. Rev. Mus. Argent. Ciencias Nat. Nueva Ser. 13 (1), 41-57.

Fernicola, J.C., 2011b. 1886-1888: Ascenso, auge y caída de la sociedad entre Florentino Ameghino y Francisco P. Moreno. In: Fernicola, J.C., Prieto, A., Lazo, D. (Eds.), Vida y obra de Florentino Ameghino, Publicación Especial de la Asociación Paleontológica Argentina, vol. 12, pp. 35-49.

Fernicola, J.C., Vizcaíno, S.F., Bargo, M.S., 2010. Localidades fosilíferas descubiertas por Carlos Ameghino en 1887 en la margen derecha del río Santa Cruz, provincia de Santa Cruz, Argentina. In: X Congreso Argentino de Paleontología y Bioestratigrafía y VII Congreso Latinoamericano de Paleontología, Actas, p. 164.

Fernicola, J.C., Vizcaíno, S.F., Bargo, M.S., Kay, R.F., Cuitiño, J.I., Toledo, N., Muñoz, N.A., Krapovickas, V., Chornogubsky, L., Hernandez del Pino, S., Gonzales, L., 2013. Localidades fosilíferas de la Formación Santa Cruz (Mioceno Inferior) en el margenmeridional del valle del río Santa Cruz, provincia de Santa Cruz, Argentina. In: XXVII Jornadas Argentinas de Paleontología de Vertebrados, p. 40. Abstract.

Feruglio, E., 1938. Relaciones estratigráficas entre el Patagoniano y el Santacruciano en la Patagonia austral. In: Revista del Museo de La Plata, nueva serie, I, Sección Geología, pp. 129-159.

Feruglio, E., 1949. Descripción Geológica de la Patagonia, vol. 2. Ministerio de Industria y Comercio de La Nación, Dirección General de Yacimientos Petrolíferos Fiscales, Buenos Aires, pp. 1-545.

FitzRoy, R., 1837. Extracts from the diary of an attempt to ascend the River Santa Cruz, in Patagonia, with the boats of H.M.S. Beagle. J. R. Geogr. Soc. Lond. 7, 114126.

Furque, G., 1973. Descripción geológica de la Hoja 58b, Lago Argentino, provincia de Santa Cruz. Bolet. Serv. Nac. Min. Geológ. 140, 1-51.

Furque, G., Camacho, H.H., 1972. El Cretácico Superior y terciario de la región austral del Lago Argentino (Provincia de Santa Cruz). In: 4 Jornadas Geológicas Argentinas, Actas, pp. 61-75.

González Ruiz, L.R., Scillato-Yané, G.J., 2009. A New Stegotheriini (Mammalia, Xenarthra, Dasypodidae) from the "Notohippidian" (Early Miocene) of
Patagonia, Argentina. In: Neues jahrbuch fur geologie und palaontologieabhandlungen, vol. 252, pp. 81-90.

Griffin, M., Parras, A., 2012. Oysters from the base of Santa Cruz formation (late Early Miocene) of Patagonia. In: Vizcaíno, S.F., Kay, R.F., Bargo, M.S. (Eds.), Early Miocene Paleobiology in Patagonia: High-latitude Paleocommunities of the Santa Cruz Formation. Cambridge University Press, Cambridge, pp. 83-90.

Marshall, L.G., 1976. Fossil localities for Santacrucian (Early Miocene) mammals Santa Cruz Province, Southern Patagonia, Argentina. J. Paleontol. 50, 1129-1142.

Marshall, L.G. Pascual, R. 1977. Nuevos marsupiales Caenolestidae del "Piso Notohipidense" (SW de Santa Cruz, Patagonia) de Ameghino. Sus aportaciones a la cronología y evolución de las comunidades de mamíferos sudamericanos. Publicac. Mus. Munic. Ciencias Nat. Mar del Plata “Lorenzo Scaglia” 2 (4), 91-122.

Marshall, L.G., Hoffstetter, R., Pascual, R., 1983. Mammals and Stratigraphy: Geochronology of the Continental Mammal-bearing Tertiary of South America. In: Paleovertebrata, Mémoire Extraordinaire, pp. 1-76.

Matheos, S.D., Raigemborn, M.S., 2012. Sedimentology and paleoenvironment of the Santa Cruz Formation. In: Vizcaíno, S.F., Kay, R.F., Bargo, M.S. (Eds.), Early Miocene Paleobiology in Patagonia: High-latitude Paleocommunities of the Santa Cruz Formation. Cambridge University Press, Cambridge, pp. 59-82.

Mercerat, A., 1890a. Notas sobre la Paleontología de la República Argentina, I. Rev. Mus. La Plata 1, 241-255.

Mercerat, A., 1890b. Notas sobre la Paleontología de la República Argentina, II. Rev. Mus. La Plata 1, 381-442.

Mercerat, A., 1890c. Notas sobre la Paleontología de la República Argentina, III. Rev. Mus. La Plata 1, 447-470.

Mercerat, A., 1891a. Datos sobre restos de Mamíferos fósiles pertenecientes a los Bruta. Rev. Mus. La Plata 2, 5-46.

Mercerat, A., 1891b. Caracteres diagnósticos de algunas especies del género Theosodon conservadas en el Museo de La Plata. Rev. Mus. La Plata 2, 47-49.

Mercerat, A., 1891c. Caracteres diagnósticos de algunas especies de Creodonta. Rev. Mus. La Plata, Rev. 2, 51-56.

Mercerat, A., 1891d. Fórmula dentaria del Gen. Listriotherium. Rev. Mus. La Plata 2, 72.

Mercerat, A., 1891e. Sobre la presencia de restos de Monos en el Eoceno de Patagonia. Rev. Mus. La Plata 2, 73-74.

Mercerat, A., 1891f. Apuntes sobre el género Typotherium. Rev. Mus. La Plata 2, $74-$ 80

Moreno, F.P., 1879. Viaje a la Patagonia Austral, emprendido bajo los auspicios del Gobierno Nacional, 1876-1877. La Nación Press, Buenos Aires.

Moreno, F.P., 1890. Reseña General de las adquisiciones y trabajos hechos en 1889 en el Museo de La Plata. Rev. Mus. La Plata 1, 57-70.

Nullo, F.E., Combina, A.M., 2002. Sedimentitas terciarias continentales. In: Haller, M.J. (Ed.), Geología y Recursos Naturales de Santa Cruz, XV Congreso Geológico Argentino, Relatorio, I-16, pp. 245-258.

Panza, J.L., 2002. La cubierta detrítica del Cenozoico superior. In: Haller, M.J. (Ed.), Geología y Recursos Naturales de Santa Cruz, XV Congreso Geológico Argentino, Relatorio, I-17, pp. 259-284.

Panza, J.L., Franchi, M.R., 2002. Magmatismo basáltico Cenozoico Extraandino. In: Haller, M.J. (Ed.), Geología y Recursos Naturales de Santa Cruz, XV Congreso Geológico Argentino, Relatorio, I-14, pp. 201-236.

Parras, A., Dix, G.R., Griffin, M., 2012. Sr-isotope chronostratigraphy of Paleogene Neogene marine deposits: Austral Basin, southern Patagonia (Argentina). J. South Am. Earth Sci. 37, 122-135.

Pascual, R., Ortega Hinojosa, E.J., Gondar, D., Tonni, E., 1965. Las edades del Cenozoico mamalífero de la Argentina, con especial atenci6n a aquellas del territorio Bonaerense. An. Com. Investig. Cienctificas 6, 165-193.

Perkins, M.E., Fleagle, J.G., Heizler, M.T., Nash, B., Bown, T.M., Tauber, A.A., Dozo, M.T., 2012. Tephrochronology of the Miocene Santa Cruz and Pinturas Formations, Argentina. In: Vizcaíno, S.F., Kay, R.F., Bargo, M.S. (Eds.), Early Miocene Paleobiology in Patagonia: High-latitude Paleocommunities of the Santa Cruz Formation. Cambridge University Press, Cambridge, pp. 23-40.

Podgorny, I., 2009. El sendero del tiempo y de las causas accidentales. Los espacios de la prehistoria en la Argentina, 1850-1910. Prohistoria Ediciones, Rosario.

Ramos, V.A., 1979. Tectónica de la región del Río y Lago Belgrano, Cordillera Patagónica, Argentina. In: Segundo Congreso Geológico Chileno, Actas, pp. B1-B32.

Riccardi, A.C., 2008. El Museo de La Plata en el avance del conocimiento geológico a fines del Siglo XIX. In: Aceñolaza, F.G. (Ed.), Historia de la Geología Argentina I, Serie Correlación Geológica, vol. 24, pp. 109-126.

Rusconi, C., 1965. Carlos Ameghino. Rasgos de su vida y su obra. Rev. Mus. Hist. Nat. Mendoza 17, 1-162.

Strelin, J., Malagnino, E., 2009. Charles Darwin and the oldest glacial events in Patagonia: the erratic blocks of the río santa cruz valley. Rev. Asoc. Geológ. Argent. 64 (1), 101-108.

Strelin, J.A., Ré, G., Keller, R., Malagnino, E., 1999. New evidence concerning the PlioPleistocene landscape evolution of southern Santa Cruz region. J. South Am. Earth Sci. 12, 333-341.

Tauber, A.A., 1994. Estratigrafía y vertebrados fósiles de la Formación Santa Cruz (Mioceno inferior) en la costa atlántica entre las rías del Coyle y Río Gallegos, Provincia de Santa Cruz, República Argentina. Ph.D. thesis. Universidad Naciona de Córdoba.

Tauber, A.A., 1997. Biostratigraphy of the Santa Cruz Formation (Lower Miocene) in southeastern Patagonia. Ameghiniana 34 (4), 413-426.

Tauber, A.A., Palacios, M.A., Krapovickas, J., Rodriguez, P., 2008. La Formación Santa Cruz (Mioceno Temprano-Medio) en la mitad occidental del río homonimo, Patagonia, Argentina. In: XVII Congreso Geológico Argentino, Actas, vol. 4, pp. 1500-1501. 
Torcelli, A.J., 1935. Correspondencia científica. In: Torcelli, A.J. (Ed.), Obras completas y correspondencia científica de Florentino Ameghino, Taller de Impresiones Oficiales del Gobierno de la Provincia de Buenos Aires. La Plata, vol. 20, p. 621.

Vizcaíno, S.F., 2011. Cartas para Florentino desde la Patagonia. crónica de la correspondencia édita entre los hermanos Ameghino (1887-1902). In: Fernicola, J.C., Prieto, A., Lazo, D. (Eds.), Vida y obra de Florentino Ameghino, Publicación Especial de la Asociación Paleontológica Argentina, vol. 12, pp. 35-49.

Vizcaíno, S.F., Kay, R.F., Bargo, M.S., 2012a. Early Miocene Paleobiology in Patagonia: High-latitude Paleocommunities of the Santa Cruz Formation. Cambridge University Press, Cambridge.
Vizcaíno, S.F., Kay, R.F., Bargo, M.S., 2012b. Background for a paleoecological study of the Santa Cruz Formation (late Early Miocene) on the Atlantic Coast of Patagonia. In: Vizcaíno, S.F., Kay, R.F., Bargo, M.S. (Eds.), Early Miocene Paleobiology in Patagonia: High-latitude Paleocommunities of the Santa Cruz Formation. Cambridge University Press, Cambridge, pp. 1-22.

Vizcaíno, S.F., Bargo, M.S., Fernicola, J.C., 2013. Expediciones paleontológicas durante los Siglos XIX y XX A la Formación Santa Cruz (Mioceno Inferior, Patagonia) y destino de los fósiles. In: 3 Congreso Argentino de Historia de la Geología, Actas, pp. 231-246. 